\title{
Penerapan Keselamatan Kerja Untuk Mencegah Penyakit Pada Perawat di Rumah Sakit
}

Christin Butar Butar

christinbutarbutar19@gmail.com

\section{LATAR BELAKANG}

Rumah sakit memiliki potensi bahaya yang disebabkan oleh berbagai faktor, yaitu faktor fisik, kimia, biologi, ergonomic, psikososial, mekanikal, elektikal dan limbah (PMK RI Nomor 66 Tahun 2016). Potensi bahaya dari berbagai faktor tersebut mengakibatkan ledakan, kebakaran, kecelakaan yang berhubungan dengan radiasi, bahan kimia berbahaya, penularan penyakit, dan sebagainya. Potensi bahaya tenaga kerja di rumah sakit lebih besar risikonya dibanding dengan tenaga kerja pada umumnya. Potensi bahaya yang ada di rumah sakit tidak hanya mengancam jiwa tenaga kerja tetapi mengancam pasien, pengunjung, keluarga dan lingkungan sekitar pasien Pelaksanaan Kesehatan dan Keselamatan Kerja (K3) adalah salah satu upaya Yng dilakukan untuk menciptakan tempat kerja yang aman, sehat, bebas dari pencemaran lingkungan, sehingga dapat mengurangi dan atau bebas dari kecelakaan kerja dan penyakit akibat kerja yang pada akhirnya dapat meningkatkan efisiensi dan produktivitas kerja. Kecelakaan kerja tidak saja menimbulkan korban jiwa maupun kerugian materi bagi pekerja dan pengusaha, tetapi juga dapat mengganggu proses produksi secara menyeluruh, merusak lingkungan yang pada akhirnya akan berdampak pada masyarakat luas. Setiap rumah sakit harus mampu melakukan pelayanan kesehatan kerja, memlakukan pengelolaan bahan bahaya dan beracun, pencegahan dan pengendalian kebakaran dan bencana, pengelolaan prasarana rumah sakit (PMK RI Nomor 66, 2016), namun pada kenyataannya masih terdapat yang belum melaksanakan hal pokok tersebut secara maksimal.

Kata kunci : Keselamatan kerja, Pencegahan Penyakit 


\section{METODE}

Dalam kajian ini, metode yang digunakan oleh penulis adalah kajian bebas (literature review), dengan cara membaca, menganalisis, menyimpulkan kajian jurnal online, textbook, e-book, serta buku pedoman yang terkait dengan pokok bahasan dari kajian yakni gambaran pelaksanaan dan penerapan dalam melakukan program kesehatan dan keselamatan kerja di rumah sakit. Dengan menggunakan jurnal dan referensi yang digunakan pada kajian bebas (literature review) ini dengan tahun terbit paling lama 2012

\section{HASIL}

Penyakit karena kerja bisa menyerang semua tenaga kerja di dalam rumah sakit, baik tenaga medis ataupun non medis karena pajanan biologi, kimia serta fisik di lingkungan kerja rumah sakit tersebut. Rumah sakit adalah tempat berkumpulnya beberapa orang sakit ataupun sehat, atau anggota penduduk baik petugas ataupun pengunjung, pasien yang mendapatkan perawatan di dalam rumah sakit dengan beberapa jenis penyakit menyebar.

Perihal ini membuat rumah sakit adalah tempat kerja yang mempunyai kemungkinan pada masalah kesehatan serta kecelakaan kerja buat petugas. Beberapa jenis penyakit yang ada di lingkungan rumah sakit sangat mungkin rumah sakit jadi tempat penyebaran penyakit infeksi baik buat pasien, tenaga kerja ataupun pengunjung. Petugas di lingkungan rumah sakit begitu berdampak dengan kontak langsung pada agent penyakit menyebar lewat darah, sputum, jarum suntuk dan sebagainya. 


\section{PEMBAHASAN}

Rumah sakit sebagai industri jasa merupakan sebuah industri yang mempunyai beragam persoalan tenaga kerja yang rumit dengan berbagai risiko terkena penyakit akibat kerja bahkan kecelakan akibat kerja sesuai jenis pekerjaannya, sehingga berkewajiban menerapkan upaya Keselamatan dan Kesehatan Kerja Rumah Sakit . (Toding, 2016). Rumah sakit memiliki potensi bahaya yang disebabkan oleh berbagai faktor, antara lain faktor biologi, kimia, ergonomi, fisik, dan psikososial yang dapat mengakibatkan penyakit dan kecelakaan akibat kerja. (Sucipto, 2014 dalam Porajow, 2017)

Penyakit Akibat Kerja adalah penyakit yang disebabkan oleh pekerjaan dan lingkungan kerja. Faktor risiko PAK antara lain: Golongan fisik, kimiawi, biologis atau psikososial di tempat kerja. Faktor tersebut di dalam lingkungan kerja merupakan penyebab yang pokok dan menentukan terjadinya penyakit akibat kerja. Faktor lain seperti kerentanan individual juga berperan dalam perkembangan penyakit di antara pekerja yang terpajan. Penyakit karena kerja bisa menyerang semua tenaga kerja di dalam rumah sakit, baik tenaga medis ataupun non medis karena pajanan biologi, kimia sertaa fisik di lingkungan kerja rumah sakit tersebut. Rumah sakit adalah tempat berkumpulnya beberapa orang sakit ataupun sehat, atau anggota penduduk baik petugas ataupun pengunjung, pasien yang mendapatkan perawatan di dalam rumah sakit dengan beberapa jenis penyakit menyebar.

Faktor risiko yang dapat menyebabkan terjadinya PAK adalah sebagai berikut:

\section{Golongan fisik}

a. Kebisingan dapat mengakibatkan gangguan pada pendengaran sampai dengan Non-induced hearing loss

b. Radiasi (sinar radio aktif) dapat mengakibatkan kelainan darah dan kulit

c. Suhu udara yang tinggi dapat mengakibatkan heat stroke, heat cramps, atau hyperpyrexia.

Sedangkan suhu udara yang rendah dapat mengakibatkan frostbite, trenchfoot atau hypothermia.

d. Tekanan udara yang tinggi dapat mengakibatkan caison disease

e. Pencahayaan yang tidak cukup dapat mengakibatkan kelahan mata. Pencahayaan yang tinggi dapat mengakibatkan timbulnya kecelakaan. 


\section{Golongan kimia}

a. Debu dapat mengakibatkan pneumokoniosis

b. Uap dapat mengakibatkan metal fume fever, dermatitis dan keracunan

c. Gas dapat mengakibatkan keracunan $\mathrm{CO}$ dan $\mathrm{H} 2 \mathrm{~S}$

d. Larutan dapat mengakibatkan dermatitis

e. Insektisida dapat mengakibatkan keracunan

\section{Golongan infeksi}

a. Anthrax

b. Brucell

c. HIV/AIDS

\section{Golongan fisiologis}

Dapat disebabkan oleh kesalahan kontruksi, mesin, sikap badan yang kurang baik, salah cara melakukan suatu pekerjaan yang dapat mengakibatkan kelelahan fisik bahkan lambat laun dapat menyebabkan perubahan fisik pada tubuh pekerja.

\section{Golongan mental}

Dapat disebabkan oleh hubungan kerja yang tidak baik atau keadaan pekerjaan yang monoton yang menyebabkan kebosanan.

Penyakit karena kerja bisa menyerang semua tenaga kerja di dalam rumah sakit, baik tenaga medis ataupun non medis karena pajanan biologi, kimia serta fisik di lingkungan kerja rumah sakit tersebut. Rumah sakit adalah tempat berkumpulnya beberapa orang sakit ataupun sehat, atau anggota penduduk baik petugas ataupun pengunjung, pasien yang mendapatkan perawatan di dalam rumah sakit dengan beberapa jenis penyakit menyebar.

Perihal ini membuat rumah sakit adalah tempat kerja yang mempunyai kemungkinan pada masalah kesehatan serta kecelakaan kerja buat petugas. Beberapa jenis penyakit yang ada di lingkungan rumah sakit sangat mungkin rumah sakit jadi tempat penyebaran penyakit infeksi baik buat pasien, tenaga kerja ataupun pengunjung. Petugas di lingkungan rumah sakit 
begitu berdampak dengan kontak langsung pada agent penyakit menyebar lewat darah, sputum, jarum suntuk dan sebagainya.

Pemicu Penyakit Karena Kerja Dalam lingkungan kerja seseorang bisa terganggu kesehatannya, serta gangguan kesehatan karena lingkungn kerja ini cukuplah banyak berlangsung. Penyakit karena kerja diantaranya berlangsung disebabkan karena situasi keadaan kerja seperti udara dingin, panas, bising, bahan kimia, debu dan sebagainya. Bahaya kimia dari obat farmasi. Bahaya radiasi sinar X-Ray, bahaya fisik lingkungan kerja, benda tajam, terjatuh, shift kerja, kelelahan, back pain, kecelakan kerja, ergonomi, kebakaran, gempa dan lainnya. Kecelakaan kerja di Rumah Sakit X merupakan salah satu bentuk masalah K3 yang perlu diupayakan pencegahan dan penanggulangannya. Pengetahuan, sikap serta pelaksanaan $\mathrm{K} 3$ tersebut dapat mempengaruhi kecelakaan kerja pada tenaga perawat merupakan salah satu upaya pencegahan dan penanggulangan kecelakaan kerja. Dari kejadian terpapar atau tertusuk jarum infeksius disebabkan oleh petugas masih melakukan recapping yaitu menutup kembali jarum dan spuit setelah digunakan dengan dua tangan, petugas masih melakukan estapet dalam pembuangan sampah benda tajam dan dikumpulkan dalam satu wadah terbuka, petugas tidak langsung membuang benda tajam atau jarum bekas pasien ke dalam safety box atau kontainer benda tajam, sampah benda tajam masih bercampur dengan sampah medis yaitu di dalam kantong plastik kuning, petugas tidak membuang sampah benda tajam ketika sudah $3 / 4$ penuh.

\section{Usaha Pencegahan Serta Pengendalian}

Supaya tenaga kerja di lingkungan rumah sakit masih efektif serta produktif dalam melakukan pekerjaan serta tanggung jawabnya dan tidak mengalami penyakit karena kerja jadi tindakan untuk menghadapi hal itu memerlukan penerapan manajemen kesehatan serta keselamatan kerja di dalam rumah sakit. Langkah awal yang peting ialah usaha pengendalian di lingkungan kerja rumah sakit diantaranya kesehatan kerja buat karyawan, sanitasi lingkungan rumah sakit, pengamanan pasien, pengunjung ataupun petugas rumah sakit dan sebagainya. 
Upaya-upaya yang bisa dikerjakan untuk kurangi serta mnghindarkan kecelakaan kerja serta penyakit karena kerja

ialah seperti berikut:

1. Lakukan substitusi pengenalan lingkungan kerja lewat cara lihat serta menganal potensial bahaya lingkungan kerja. Mengganti perlengkapan kerja yang tidak wajar gunakan.

2. Pelajari lingkungan kerja dalam perihal ini menilai karakter serta besarnya potensipotensi bahaya yang mungkin muncul hingga dengan mudah bisa mengutamakan dalam menangani permasalahan yang lebih potensial.

3. Pengendalian lingkungan kerja dengan bertindak mengurangi bahkan juga menghilangkan pajanan pada masalah kesehatan pekerja dilingkungan kerja lewat cara teknologi pengendalian.

4. Pengendalian administratif dengan memperingatkan pekerja agar bisa memakai alat pelindung diri yang benar dan baik, membuat rambu-rambu bahaya dilingkungan kerja yang punya potensi bahaya.

5. Kontrol kesehatan pekerja dengan berkala untuk mencari aspek pemicu serta upaya penyembuhan.

6. Pendidikan serta penyuluhan kesehatan serta keselamatan kerja buat pekerja di lingkungan rumah sakit.

7. Pengendalian fisik lingkungan kerja, mengidentifikasi suhu, kelembapan, pencahayaan, getaran, kebisingan, pengendalian sistem ventilasi dan sebagainya.

8. Lakukan pengawasan serta monitoring dengan berkala pada lingkungan kerja rumah sakit.

9. Substitusi berbahan kimia, alat kerja serta mekanisme kerja. 


\section{PENUTUP}

\section{Kesimpulan}

Kemungkinan petugas rumah sakit pada gangguan kesehatan serta kecelakaan kerja biasanya dikarenakan oleh perilaku petugas dalam kepatuhan melakukan tiap-tiap mekanisme pada kewaspadaan. Lihat hal diatas tentu saja kita perlu mengerti jika dalam cakupan pekerjaan di bagian kesehatan memiliki banyak resiko pada kesehatan pekerja. Pelaksanaan pembinaan dan pengawasan perlengkapan keselamatan kerja yang telah dilaksanakan pihak rumah sakit yaitu telah menyediakan APD berupa sarung tangan, masker, APAR lengkap dengan SOP penggunaan, adanya jalur evakuasi dan titik kumpul untuk keadaan darurat.

Maka dari itu, K3 mutlak dilaksakan pada setiap jenis bidang pekerjaan tanpa terkecuali. Terutama bagi tenaga kesehatan, selain memiliki hak dan kewajian terdapat juga keputusan menteri bagi tenaga kerjakesehatan. Bagi tenaga kesehatan khususnya perawat, tidak sedikit angka kejadian penyakit perawat yang disebabkan oleh lingkungan kerja. Sehingga perawat berhak mendapatkan fasilitas kerja yang memadai.

Saran

Untuk mencegah perawat terjangkit penyakit yang disebabkan kerja di rumah sakit dilakukan pemeriksaan kesehatan sebelum bekerja, pemeriksaan kesehatan berkala dan pemeriksaan kesehatan khusus. Saat melakukan tindakan, perawat harus mengikuti panduan petunjuk teknis dan SOP, karena rumah sakit telah menyediakan alat keselamatan dan juga SOP penggunaannya. 


\section{DAFTAR PUSTAKA}

Christi Debora Tamboto, Grace D Kandou, Poul A.T. (2017). Analisis Penerapan Standar Pelayanan Kesehatan Kerja di Rumah Sakit GMIM Kalooran Amurang Kabupaten Minahasa Selatan. Fakultas Kesehatan Masyarakat Universitas Sam Ratulangi

Hasbi Ibrahim, Dwi Santy Damayanti, Munawir A , Sunandar. (2017). Gambaran Penerapan Standar Manajemen Keselamatan dan Kesehatan Kerja Rumah Sakit Umum Daerah Haji Makassar. Public Health Science Journal,Vol 9(2), 343-347

Herman, M.J, Handayani . (2016). Sarana dan Prasarana Rumah Sakit Pemerintah Dalam Upaya Pencegahan dan Pengendalian Infeksi di Indonesia. Jurnal Kefarmasian Indonesia, Vol 6(2)

Liza Salawati. (2015). Penyakit Akibat Kerja dan Pencegahan.Jurnal Kedokteran Komunitas Universitas Syiah Kuala Banda Aceh

Setya Putri, Santoso, Endang Purnawati Rahayu. (2018). Jurnal Endurance, Vol 3(2), 271277

Silvia Mana, Joko W, Erlisa Candrawati. (2015). Kejadian Kecelakaan Kerja Perawat Berdasarkan Tindakan Tidak Aman. Jurnal Care Vol 3(2)

Simamora, R. H. (2020). Pelatihan Komunikasi Efektif untuk Meningkatkan Efikasi diri Perawat dalam Pelaksanaan Identifikasi Pasien. JURNAL ILMIAH KESEHATAN MASYARAKAT: Media Komunikasi Komunitas Kesehatan Masyarakat, 12(1), 49-54.

Simamora, R. H. (2011). ROLE CONFLICT OF NURSE RELATIONSHIP WITH PERFORMANCE IN THE EMERGENCY UNIT OF HOSPITALS RSD DR. SOEBANDI JEMBER. The Malaysian Journal of Nursing, 3(2), 23-32.

Sudarmo, Zairin Noor H, Lenie Marlinae. (2016). Faktor Yang Mempengaruhi Perilaku Terhadap Kepatuhan Penggunaan Alat Pelindung Diri (APD) Untuk Pencegahan Penyakit Akibat Kerja. Jurnal Berkala Kesehatan, Vol 1(2), 88-95

Sucipto, Cecep Dani. 2014. Keselamatan dan Kesehatan Kerja. Yogyakarta : Gusyen Publishing 
Tukatman, Sulistiawati, Purwaningsih, Nursalam. (2015). Analisis Keselamatan Dan Kesehatan Kerja Perawat Dalam Penanganan Pasien di Rumah Sakit Benyaman Guluh Kabupaten Kolaka. Jurnal Ners Vol 10(2), 343-347

Widiwati Rinjani Octavia, A.T Diana Nerawati, Ernita S. (2018). Penerapan Pelayanan Kesehatan dan Keselamatan Kerja Pada Perawat IGD Rumah Sakit Umum DR Wahidin Sudiro Husada Mojokerto. Jurnal Gema Kesehatan Lingkungan Vol 16(1) 